\title{
NATIVE ENGLISH-SPEAKING TEACHERS AND NON-NATIVE INSTRUCTORS IN TRAINING EFL IN UKRAINE: STUDENTS' PERCEPTIONS
}

\author{
Tatyana Aksiutina ${ }^{1}$ \\ Oksana Vovkodav ${ }^{2}$
}

DOI: https://doi.org/10.30525/978-9934-26-051-3-1

\begin{abstract}
With the mushrooming use of English and number of nonnative speakers, the issue of teaching English in non-English contexts has been brought to the fore in discussions and empirical research. The question, who makes better language teachers of English, has received considerable attention in the literature on native English-speaking teachers (NESTs) and non-native English-speaking teachers (NNESTs). The current study examines the contributions of native and non-native teachers to an English Language Teaching (ELT) program in Ukraine. It contends that, in spite of a recent upsurge in writing on non-native English-speaking teachers (NNESTs) in the global discourse of English language teaching (ELT), the experiences of NNESTSs working within their own state educational systems remain seriously under-investigated. The purpose of the study is to explore the general perceptions of university students of NESTs and NNESTs in Ukraine. It also aims to find out with whom Ukrainian university students believe they learn more: with native or with non-native EFL teachers.

This paper reports on the results of the study conducted at Oles Honchar National University with 158 undergraduate students majoring in German, French, Ukrainian Philology as well as International Relations to assess 2 male native English-speaking (NEST) and 10 non-native English teachers. A selfdeveloped anonymous questionnaire is applied to seek their views about NESTs and NNESTs on rating scales relating to language skills, grammar, vocabulary, pronunciation, learning strategies, culture and civilization, attitudes and assessment. The study also views how these teachers are able
\end{abstract}

\footnotetext{
${ }^{1}$ English Lecturer of the Department of English Philology, Oles Honchar Dnipro National University, Ukraine

${ }^{2}$ English Lecturer of the Department of English Philology,

Oles Honchar Dnipro National University, Ukraine

(C) Tatyana Aksiutina, Oksana Vovkodav
} 
to teach certain language skills and areas. Descriptive statistics were run for data analyses. It has been found out that the participants of this study have exhibited positive attitudes towards their NETs and NNETs. Though the results have shown an overall preference for NETs but it seems that the respondents also believe that NNETs effectively contribute by virtue of their own experiences as English language learners and their experience as teachers. It may be concluded that Ukrainian EFL learners represented by the participants of this survey believe that NETs are more successful in creating richer classroom environment, teaching/assessing speaking skills, listening skills, vocabulary and reading skills better. The findings reveal that NNETs use innovative strategies and explain lessons more clearly to make their students learn better. By virtue of their personal experiences as language learners themselves, they have been perceived to understand their students' styles and language difficulties in a better manner that facilitate learning process. Therefore, it may be concluded that each group of teachers has been perceived to have their own particular strengths and weaknesses.

\section{Introduction}

With the growing use of English and number of non-native speakers, the issue of teaching English in non-English-dominant contexts has been highlighted in discussions and empirical research. Signifying this issue of English acquisition, they inevitably arose the question: who makes the best EFL teachers - native (NEST) or non-native English-speaking teachers (NNEST)? [31, p. 137; 32, p. 343; 44, p. 382; 46, p. 78]. Although ELF scholars have voiced different opinions on issues relating to nativeness [21, p. 243; 32 , p. 345; 37, p. 25], empirical research focusing primarily on NNES teachers and students' perceptions [24, p. 133] is scarce. Most of the current research has been conducted in the USA and East Asian contexts, and has focused on the attitudes of participants towards either NEST or NNEST, but rarely towards two groups at the same time. However, in Ukraine, to which this study belongs, not many studies were found examining students' perceptions of EFL NES and NNES teachers in the context of higher education, where students are more likely to study with NNEST along with NEST.

Another major gap in the literature is that previous research on students' perceptions of NNESTs and NESTs has not paid attention to whether participants have encountered or had any previous experience with NESTs. 


\section{Research objectives}

This study is an attempt to fill this gap in the literature and investigate the Ukrainian students' perceptions towards their NESTs and NNESTs. This article examines the contributions of native and non-native teachers to an English Language Teaching (ELT) program in Ukraine. It contends that, in spite of a recent upsurge in writing on non-native English-speaking teachers (NNESTs) in the global discourse of English language teaching (ELT), the experiences of NNESTSs working within their own state educational systems remain seriously under-investigated. The purpose of the study is to explore the general perceptions of university students of NESTs and NNESTs in Ukraine. It also aims to find out with whom Ukrainian university students believe they learn more: with native or with non-native EFL teachers.

The study is relevant in different aspects. Firstly, it can serve as an empirical study to investigate Ukrainian students' perception of their learning preferences for both NESTs and NNESTs. Second, it can also be taken as a reference for EFL learners to get a better understanding of the students' awareness of the potentials of different English language teachers with regard to NESTs and NNESTs. Finally, both NESTs and NNESTs who seek professional development can gain some insights from the findings and take them into consideration in teaching the English language.

Ukraine has been ranked in the expanding circle of concentric circle model, where English is used primarily as a foreign language. Traditionally, learning and teaching ESL/EFL has been predicated on the distinction between native and non-native speakers [3, p. 32]. In Ukraine's ESL/EFL context, non-native English speaking teachers (NNESTs) still predominate over native English speaking teachers (NESTs). Although there is higher number of NNESTs, NESTs seem to be favored more in the field of English teaching. They are often viewed in Ukraine as well as around the world as the embodiment of the English standard. Native speakers are endowed by non-native speakers with high level of credibility. In turn, non-native speakers are expected to mimic the native speaker's vocabulary, grammar, idioms and culture.

Although there are more and more voices for more equality between native and non-native teachers, the actual situation is quite another story. Todd \& Pojanapunya (2009) focus on the conflict between the educational principle of parity between NESTs and NNESTs and the commercial realities of Ukraine. Language private schools and courses offering English 
language programs often promote themselves as employing NESTs. Ukrainian students aspire to the American English standard, which has, in turn, led to a blind adoration of native-speaker as the norm. Although more and more EFL learners accept the concept of "World English", it is not easy for many to alter their conscious preference for native speakers.

\section{Literature review}

\section{Defining native and non-native speakers}

The academic literature defines the notions native speaker and nonnative speaker in different ways. According to Macmillan Dictionary Online, native speaker is "someone who has learnt a particular language from the time that they began to speak". Suarez (2000) argues that the term native defines the locality in which one was born or raised, and has a positive connotation in the ELT area. On the other hand, the term nonnative negatively affects the morale of teachers who feel inferior when they compare themselves to their native peers.

Lee (2005) as well as Kubota (2004), Maum (2002) and Medgyes (1992) define the native speaker as the person who acquired the language in early childhood and maintains its use so (s) he can identified by a linguistic community; the individual who has an intuitive knowledge of the language; a person with no foreign accent who can produce a fluent, spontaneous discourse, and communicate in various social conditions. This suggests that adult language learners can never be native speakers of a language other than their first. Yet there are some adult learners who aim to achieve nativelike speaking and high level of proficiency in the target language.

The notion of non-native has generated a lot of debates [33, p. 344] for over two decades in the EFL / ESL field. These debates resulted in many related definitions of non-native English speakers made by prominent scholars in the field [10, p. 363] ("more or less accomplished users of English", "expert speakers and affiliation", "English-using fellowships to stress" and "Weness instead of the 'us and them' division" [10, p. 356].

The reason for these transformations is the increase in the number of bilinguals and polyglots who are able to communicate fluently in two, three or more languages. Besides, there are more and more cultures where English is replacing the local language, and this is no longer about the former colonies of Great Britain, but about countries such as the Netherlands, 
Sweden, Denmark, where English is actively penetrating into various areas, gradually replacing the native language of these countries. People start learning English since childhood, and are surrounded by an Englishspeaking environment, at the same time they speak the local language and are surrounded by their native culture. The question arises about the cultural and linguistic identification of such people.

Native researchers perceive the notions native speaker and non-native speaker as identical to each other [8]. In the local linguo-didactic discourse, the term native speaker is used as the model of EFL teaching. For example, learning English as a foreign language with a native teacher is considered more effective and appreciated more than learning a language with a non-native teacher [5, p. 12; 7], and the highest goal in language acquisition is the level of effective functioning (C1-C2), which equals to the level of an educated native speaker $[1$, p. $337 ; 2$, p. 440]. Therefore, the authority and prestige of NNESTs in this country is very high. NNESTs look up to them, imitate them.

\section{Status of native English-speaking teachers and non-native speaker teachers in EFL teaching}

Discussions regarding EFL teaching by either NESTs or NNESTs, comparing them in terms of their teaching quality and their students' preferences, have become a major issue as a result of the increased demand for English and the growing number of NNESTs in the field. This heated debate has led to a multitude of empirical studies examining NEST and NNEST from different perspectives. Among these points of view, evaluative studies immediately stand out. For example, previous research from China to the United States has shown that, in general, students view their NNESTs positively in their countries [13, p. 261; 30, p. 128; 34, p. 752]. What is remarkable about these studies is that over time there seemed to be an increase in positive attitudes towards NNEST. Lewier and Bilmona argue that although many people prefer NESTs as the best ones, NNESTs may also have some superiority over the NESTs, and students may benefit from NNESTs more than NESTs in some cases [8]. According to Medgyes (1994), a NNEST can predict and prevent students' possible problems with the language, (s) he can talk to students in their first language, and (s) he can teach language learning strategies more successfully since (s) he can be a better and more realistic learner model of English. (S) he can be more 
sensitive to students. In another work, Medgyes (1994) states that NNESTs generally feel unsafe while speaking the language which they are teaching [7]. As a consequence of this feeling, they become more pessimistic and more aggressive. It becomes clear that pessimistic NNESTs spare less time on pronunciation and vocabulary than they do on grammar.

Ryan (2005) points out that teachers' attitudes and belief strongly affect students' behavior [15]. Native teachers show more self-esteem than nonnative teachers. Bulter (1998) examines the influence between native and non-native teachers' accents on students' performance; the result indicates that native teachers tend to have more confidence in their use of English. NESTs are more aware of learners' needs, they speak English more confidently, and they are potentially more accomplished users of English.

Some scholars claim that NESTs use authentic oral language and provide students with more cultural information. Supportively, Modiano (2008) states that especially young learners have positive attitudes towards their NESTs as they display a good model of the target language. In a similar vein, Lasagabaster and Sierra (2009) conclude that students' perceptions toward NESTs are quite positive regarding their development of language skills such as speaking, writing, and reading. Parallelly, Falk (2002) stresses the idea that target language students who admire the culture, like the people that speak the language, have a desire to become familiar with or even are eager to integrate into the society in which the language is used are the most successful ones. Additionally, Rampton (1990) argue that for most cases students are in favor of NESTs, claiming that students are willing to learn from native speaker in a way that they have a desire to enter into the target language and interact with the native speakers.

Another aspect that can play a determining role in perceptions of students towards NESTs in education field is motivation. Shimizu (1997) emphasizes that motivation of the students could be detrimentally affected by the negative attitudes of students towards their teacher [1]. Unfortunately, such an influence is not limited to the classroom context; it can sustain its adverse effect throughout the learning experiences of students. Dornyei (1997) suggests that whoever the teacher is, native or non-native, he or she should promote integrative values by encouraging a positive and open-minded disposition towards the target language and its speakers in such a way that language learners can develop a positive attitude towards native speakers. It is suggested that only in this way students can best benefit from native speakers. 
Medgyes (1994) notes that an ideal native-speaking English teacher should possess a high degree of proficiency in the learner' mother language. It could be easier for NESTs in the EFL setting, but compared to that in the EFL setting, NESTs would have difficulties in the ESL setting. In Medgyes' book, he discusses the differences between native and non-native English speakers' use of English, general attitude, attitude to teaching language, and attitude to teaching culture. In terms of their use of English, he notes that NESTs use real English and use it more confidently compared to NNESTs. This argument has been questioned by those who stress that a native speaker does not mean to inherently speak his first language well $[16$, p. $189 ; 30$, p. $132 ; 37$, p. 26]. Using language as the first one is not necessarily equal to language competence. Barratt and Contra accuse NESTs of discouraging learners since they have no capacity or willingness to make comparisons and contrasts to the students' native language. Despite such disadvantages native speakers are still more popular and preferable in the English language teaching profession.

The assumption that NESTs are the best teachers has never been pedagogically tested. Bueno (2006), rejecting the idea that NEST is better, says: "I don't know of a single study that shows that they are better than a teacher; however, the long-standing belief that they are better is still absent without any evidence to support such a theory".

Most of the related studies have not found a consensus on who is the best native or non-native English teacher. This shows that both NEST and NNEST have merits and demerits, and it is unfair to judge one group based on their problems [27, p. 160; 29, p. 128; 36, p. 118]. Luksha and Solovova (2006) note that both NESTs and NNESTs who speak English have certain internal advantages and disadvantages, but this depends on the personality and their abilities [3]. They argue that a good teacher is one who: knows the subject; ready to share knowledge; loves work; always ready for the unexpected; has a lot of patience. Liu (2008) found that learning together between NEST and NNEST can improve the quality of learning for both of their. Park (2009) considers the combination of native English-speaking teachers with nonnative speaking teachers to be an appropriate pedagogical behavior.

"What difference does being native speaker of English make in the ESL/ EFL classroom? Cook (1994) argues that language teaching would benefit by paying more attention to the ESL user rather than concentrating on the 
native speaker. One group of teachers should not necessarily be superior to another. What teachers should care about is how to improve their teaching through more professional training in linguistics and sociolinguistics. Most of all, they need to understand better the students' needs. Nunan (2006) asserts that "if English is a necessity, steps should be taken to ensure that teachers are adequately trained in language teaching methodology appropriate to a range of learner ages and stages, that teachers' own language skills are significantly enhanced, that classroom realities meet curricular rhetoric, and that students have sufficient exposure to English in instructional context" [2]. In Ukraine, English has become a necessity. Steps have also been taken to increase English proficiency in general. However, the outcome is far from being realized. Students' communicative competence has long been neglected and hindered due to teacher-related, student-related, and educational system constraints. Teacher-related problems derive largely from NNEST's deficiency in spoken English and lack of socio-linguistic and cultural sophistication [3]. Students' low proficiency in English and passive learning style do not help matters. Student reticence and passivity has a cultural interpretation. Although different perspectives exist, many foreign teachers express a good deal of frustration in the face of student reticence and passivity.

It is well-known that traditional EFL instruction in Ukraine focuses on teacher-centered, grammar-translation, and exam-oriented approaches. These approaches fail to meet the students' need to express or comprehend messages in English when they study abroad. Ko (1992) attributes students' low proficiency in English to inappropriate teaching methods. Scovel (1983) notes grammar-translation and exam-oriented assessment make it harder for ESL/EFL students to use English as a communicative medium.

Assuming that the official national language, Ukrainian, is best taught and learned from a native Ukrainian speaker, then it certainly would follow that English ought to be accorded the same pedagogical consideration. From a linguistic point of view, it is easy to observe the difference between NESTs and NNESTs in terms of language competence. Phillipson (1996) uses the term "the native speaker fallacy" to refer to unequal treatment of non-native English speakers. In Ukrainian private language schools, NESTs are paid higher wages and receive more respect from students and parents alike. A mere manipulator of the language, however, does not guarantee a good English teacher in the classroom. Ebele (1999) notes that: 
English speakers benefit from the usual exotic allure of any foreign language, and they benefit from the commonly accepted idea that their native language is a practical skill useful in the workplace. In many cases, they were hired for teaching jobs solely on the basis of being a native speaker [5, p. 339].

This study indicates that the native speaker still has a privileged position in English language teaching; native speakers represent both the model speaker and the ideal teacher.

\section{Research method}

The present study has been carried out in Oles Honchar Dnipro National University with Ukrainian students who are taught English by both native and non-native English speaking teachers. It is aimed at investigating students' perception and attitudes rather than at testing certain variables $[17$, p. 22]. So, to elicit students' attitudes towards studying English with NESTs and NNESts an anonymous self-report questionnaire was offered to complete.

\section{Participants}

Participants, totaling 158 undergraduate students (36 males and 122 females) of German, French, Ukrainian Philology Department and the Department of International Relations, were under 22, (mean age 20 years); and the number of years of studying English ranged from 8 to 14 years, (mean 8.5 years). 81 were Philology Studies, 77 majored in International relations. These students were chosen because they had been taught by both groups of teachers at the same time for two semesters to express their perceptions of their instructors. The teachers were 2 male native (from the United States and Great Britain) and 10 non-native instructors (from Ukraine). They all share with the students the target language learning experience, but the Ukrainian teachers share in addition the students' native language. Most of the NNESTs and NESTs are lecturers with Master degrees in English literature or linguistics ( 2 are PhD holders in Foreign Literature). These teachers are aged between 35 and 50, having diverse experiences (6 to 30 years) of teaching English as a second/ foreign language in various institutions at different levels. Almost all NNESTs were taught by both NESTs and NNESTs and they have an average of 15-year-experience working with native speaker teachers of English. 


\section{Data collection instrument}

The tool for collecting the data was an anonymous self-report questionnaire in English, and interviews which elicited the students' attitude towards learning English with NES and NNES teachers. These tools aimed to collect a large amount of data in an easily processed form, methodologically similar to other questionnaire studies on this topic $[11$, p. $199 ; 14$, p. 80; 22, p. 63; 34, p. 753; 35 , p. $250 ; 39$, p. $128 ; 43$, p. 13]. The data collected were in the nature of an attitude [18], allowing to reveal the attitudes and beliefs of the participants about the problem under study. To get an overview of the problem, an open format was used. This format was more suitable for research than a closed-item questionnaire because we could not anticipate the topics that might arise, and, therefore, could not provide pre-prepared response categories [18]. The questionnaire consisted of 18 statements. The general perception component was assessed on the basis of 13 statements regarding the reasons underlying students' perception of their teachers of both native and foreign English. The second component consisted of four statements and aimed to collect information about students' perceptions of NEST and NNEST based on the teaching strategies used by teachers in the classroom. Each item on the questionnaire included two options (NESTs NNEST). The respondents were asked to choose one. The questionnaires were written and responded to in English. Because the study does not test English language proficiency, textual errors are ignored in the analysis except where meaning is unclear, in which case the data are excluded.

The open-ended questionnaires were distributed to the students by two research assistants in May 2020. The participants volunteered to participate gave their consent and were asked to complete the questionnaires during class time. The questionnaires took approximately 20-30 minutes to complete, and the return rate of the questionnaire was $100 \%$.

The questionnaires were anonymous and no other identifying data was collected. The collected data were quantified according to the themes by a researcher in the coding framework presented in the left-hand column of Table 1.

\section{Limitation of the study}

The sample is limited in the number of subjects surveyed and is restricted to only one university. The study only covers native (2) and non-native (10) teachers of English as well as 98 undergraduate students at Oles Honchar Dnipro National University located in Dnipro, Ukraine. 
Table 1

\section{Ukrainian students' perceptions of their NESTs and NNESTs}

\begin{tabular}{|c|c|c|}
\hline \multirow[b]{2}{*}{$\begin{array}{l}\text { Students' perceptions of NNESTs and NESTs } \\
\text { Personality traits } \\
1-\text { I feel more comfortable in class with a (native / nonnative) } \\
\text { English teacher. } \\
2-\text { The (native / non-native) English teachers are outgoing, } \\
\text { natural, sociable, active, and excite feelings of emulation } \\
3 \text { - It is easy to communicate with a (native/ non-native) English teacher }\end{array}$} & \begin{tabular}{|l|l|} 
NESTS \\
\end{tabular} & NNESTs \\
\hline & $43 \%$ & $28 \%$ \\
\hline $\begin{array}{l}\text { Linguistic competence } \\
\text { 4-I would improve my pronunciation with a (native / nonnative) } \\
\text { English teacher } \\
5 \text { - I would learn to speak natural, native-like English with } \\
\text { a (native / nonnative) English teacher } \\
6 \text { - I would improve listening skills with a (native / nonnative) } \\
\text { English teacher } \\
7 \text { - I would improve reading skills with a (native / non-native) } \\
\text { English teacher } \\
8-\text { A (native / non-native) English teacher is more competent in } \\
\text { teaching grammar }\end{array}$ & $92 \%$ & $85 \%$ \\
\hline $\begin{array}{l}\text { Cultural Similarities and Differences } \\
9-\text { A (native/non-native) English teacher motivates me to learn } \\
\text { about English-speaking people and their culture } \\
10-\text { A (native/non-native) English teacher knows the students' } \\
\text { culture and can behave appropriately }\end{array}$ & $27 \%$ & $11 \%$ \\
\hline $\begin{array}{l}\text { Pedagogical Skills } \\
11-\text { A (native / non-native) English teacher is more responsive } \\
\text { to the learners' needs } \\
12-\text { A (native/non-native) English teacher is able to make EFL } \\
\text { learning relevant and fun } \\
13-\text { A (native/non-native) English teacher is experienced because } \\
\text { he is more conscious of the students' learning styles. } \\
14-\text { A (native / non-native) English teacher knows their students' } \\
\text { difficulties }\end{array}$ & $66 \%$ & $34 \%$ \\
\hline $\begin{array}{l}\text { Teaching Strategies } \\
15 \text { - Native / nonnative English teachers are good at motivating } \\
\text { students, able to encourage independent learning and thinking } \\
16 \text { - Native / nonnative English teacher can explain some difficult } \\
\text { problem for us effectively } \\
17-\text { A (native / non-native) English teacher would use innovative } \\
\text { teaching strategies to help students learn better } \\
18 \text { - If I could choose a teacher myself, I would choose a course } \\
\text { taught by (a native / a non-native) English teacher }\end{array}$ & $32 \%$ & $68 \%$ \\
\hline
\end{tabular}




\section{Findings}

In the open questionnaire responses, the most frequently cited strengths of NETs were their personality traits. NESTs were viewed as being good at communicating with students, creating a relaxed classroom atmosphere $(85 \%) .72 \%-83 \%$ of the students stress the point that NESTs teachers are active, outgoing, humorous, and can easily break the boredom during classes. As for the issue, who can teach better, intriguing was that NNESTs were viewed as being good at communicating with students (NNESTs $57 \%$; NESTs $-43 \%$ ). It can be considered as a result of speaking the same mother tongue with students and sharing the same culture. Besides, nonNESTs can easily sympathize with students at elementary level regarding the language learning process.

Ukrainian students are mostly likely to interact with a teacher of an opposite culture. Students like to communicate with a native teacher in a relaxed classroom setting without any sense of fear. Such a relaxed teaching-learning environment motivates students to speak the target language and achieve an ultimate aim of language learning. Moreover, the NESTs are friendly and more lenient toward students' mistakes and attendance. Very often NESTs are not particular about discipline and informality. In addition, in a class taught by NEST, students are sometimes allowed to chat, to move, to leave the class at any time without permission, and to use their native words without any blame on the part of the teacher. One student said, "I have the sense of feeling at home in a class taught by a native teacher". Students state that such behaviors may not be accepted by a non-native teacher who may not allow students to discuss any topic irrelevant to the lesson or spend the time without focusing on the lesson. At the same time, some respondents perceived NESTs to set unrealistic expectations on students, to behave inappropriately, and to be arrogant (9\%).

The most common perceived advantage of learning English from a NEST was exposure to native pronunciation as a model for linguistic output (95\%), enabling respondents to improve their pronunciation by imitating a native speaker's talk "just like babies do". The respondents commented that "you can correct your pronunciation, intonation. And you can speak English more naturally" (Wu \& Ke, 2009). Conversely, students listed pronunciation as by far the most salient disadvantage of a non-NEST. 
"The pronunciation of a non-native-speaker teacher is normally not as good exact as a native speaker teacher" [41, p. 34].

Native teachers can speak English more fluently so they can teach speaking and listening and reading skills more effectively. Facilitating learning speaking (96\%) and listening reading skills (92\%) were also advantages ascribed to NETs. While some respondents revealed that more opportunities to speak English in a NET's class resulted in enhancing their English speaking and communication skills, others stated that they could improve their listening skills just by listening more to NETs during the lessons. These findings are in line with the advantages suggested by Beare (2013) and are also similar to the findings in other studies. In both Cheung's (2002) study in Hong Kong and Mahboob's (2003) study in the United States, the participants also reported that NESTs had better oral skills. Furthermore, Luk (1998) and Moussu (2002) identified NNESTs' English pronunciation to be an inadequate model for L2 pronunciation. One factor that may be related to this issue is that many NNESTs may actually have very little experience speaking English. They may never have had a NEST and may have learned English in a more traditional classroom involving heavy bookwork and very little communicative language learning. However, Kirkpatrick (2010) recently argued that phonological proficiency in Ukraine should not be measured by NES standards. Instead, it should only be measured in the learners' ability to use English effectively and intelligently to communicate with other English speakers [23].

With regards to the linguistic dimension, students were mainly doubtful about NESTs' poor grammar knowledge (15\%), which is quite important for EFL learners due mainly to their concerns about exams. Students explain this point, stating: "We're having difficulty in learning complex and complicated grammatical structures with NESTs. Non-native teachers can simplify such intricate rules".

However, more than half of the students commented that it was easier to catch up with the speech of a NNEST than the speech of a NEST. $58 \%$ of the participants stated that understanding a NEST was harder for them which might result in an ineffective communication atmosphere.

A frequently mentioned benefit of learning from a NEST was becoming familiar with the teacher's culture ("I believe that NESTs are more knowledgeable. They possess the target culture. That's why, I think 
they perform more efficiently at teaching"). This result is unsurprising, as fascination with other countries and cultures is a common motivation for learning English a second language (also reported by Mahboob, 2003) as indicated by $89 \%$ of the sample. Students justified their responses as they find that natives manifest their culture naturally in their behaviors and their verbal and non-verbal communications. One student remarked that a native teacher is a real and live representative of the foreign culture and he can definitely teach his language better than a teacher from a different culture. The respondents state that NESTs can clearly inform difference between Ukraine and their countries. This finding echoes Ryan (1998), who argues that awareness about social/cultural groups is a key part of the knowledge that teachers bring to language classrooms.

Many students draw attention to the fact that experienced teachers can help students more than inexperienced teachers. $82 \%$ of the sample agreed that NNESTs are experienced because they are more conscious of the students' learning styles than NESTs. Another $68 \%$ of the respondents believe that NNESTs are more competent due to their awareness of the students' culture and learning needs. In addition, $77 \%$ of the sample have the belief that NNESTs know the English language difficulties due to their shared linguistic background. Local teachers attribute their ability to anticipate students' errors also to their own previous English learning experiences [16, p. 198; 32, p. 347]. NNESTs can teach language learning strategies more effectively (Medgyes, 1994). Formal English learning helps them develop linguistic awareness and enables them to provide students with adequate linguistic information about the language [33, p. 346]. They may be more sensitive to students' learning problems [12;27, p. 162] and may anticipate their learning difficulties, especially when they share L1 with students (L1) [37, p. 27]. Moreover, they can be more responsive to students' needs [30, p. 139; 33, p. 344] and can set realistic learning goals. Boyle (1997) adds that cultural affinity with students also favors non-native teachers in the context of English as a foreign language.

The last grouping of questions is related to the NESTs' and NNESTs' teaching methodologies and pedagogy. In these terms, NESTs scored significantly higher. Analysis of students' responses came to emphasize the positive reflection of Ukrainian university students towards their NESTs. $63 \%$ of the respondents prefer the way NESTs deliver their classes and agree 
that NESTs would use ground-breaking teaching strategies to help students learn better. One student said "a NEST teaches us how to learn. He always listens to us and speaks less". For this reason, $62 \%$ of the participants are in favor of the teaching strategies NESTs use as they aim toward enhancing independent learning and focus on the process more than the outcome. In addition, $78 \%$ of the participants highlight that NESTs encourage and develop students' confidence to use the language in class as well as assimilating everyday situations in class. Therefore, $71 \%$ of the sample made it clear that if they are to choose a teacher for a specific English language course, they would choose a course taught by a native English teacher. One student said "a native teacher involves us in group activities most of the time and in his class we feel like true humans rather than empty cups to be filled with knowledge". Another student added "my native teacher doesn't stop us when we make mistakes and always appreciates our contributions regardless of how right or wrong it is". On the other hand, $69 \%$ of the participant stressed that a nonnative English teacher would explain lessons more clearly than a native.

The findings of these questions are also similar to several other studies. Both Medgyes (1994) and Arva and Medgyes (2000) reported differences in teaching behavior and methodology between NESTs and NNESTs. Both studies indicated that NESTs used a wider variety of resources in the classroom and that NNESTs mostly relied on a single textbook. Arva and Medgyes (2000) also reported that NESTs tended to use more authentic English resources in the classroom. Benke and Medgyes (2005) also examined Hungarian EFL learners' perceptions of the differences in teaching behavior between NESTs and NNESTs. One of the findings in their study was that NNESTs preferred to use more traditional teaching methods, which would include direct instruction using a textbook.

This is not the case with studies such as Madrid (2004); Liu and Zhang (2007) and Park (2009) as students prefer both. Some students justified their responses stating that they would need NNESTs at lower levels of education as they need a teacher who shares the same language and cultural background, but when they go higher up to the university level a NEST would be more helpful. This is consistent with Torres (2004), Madrid (2004), and Lasagabaster and Sierra (2002) who found that adult ESL students' general preference for NESTs increases as they move to more advanced levels of study. 


\section{Discussion}

The current study responds the questions about how NNES and NES teachers are perceived by Ukrainian students and what qualities they bring to the language class.

The findings revealed mark significant difference in the respondents' perceptions of their NESTs and NNESTs. In particular, the data collected shows that NESTs are valued as models for authentic, natural pronunciation, despite problems with comprehension. Grammatical explanations were not seen as a NESTs' strength (Benke \& Medgyes, 2005). Respondents enjoyed the exposure to NESTs' culture, but they also faced a cultural and communication gap in NESTs' classrooms. What is more, NESTs could not communicate at L1 level with their students. Non-NEST pronunciation was considered inaccurate and less fluent than that of native speakers, but respondents rated their ability to switch to L1 when required. In addition, respondents valued the ability of non-NESTs to explain complex grammar. While some respondents criticized the limited knowledge of non-NEST English-speaking cultures, others appreciated working with teachers who shared their own cultural norms and values.

The study states that the non-NESTs' multilingual competence was a gift for English learners in two groups of participants because it reinforced three main perceived benefits of non-NEST: their ability to switch codes when teaching complex subjects, their understanding of students' learning difficulties, the ease for students in understanding their teaching, and effective communication between students and teachers, their understanding of the complex nature of second language learning, and their pedagogical competence based on their own experiences as second language learners $[20$, p. 86]. The use of the L1 as a perceived advantage confirms one of the six hypotheses suggested by Medgyes (1994) regarding the positive aspects of being an NNEST: making use of the learners' mother tongue. This finding was also in agreement with previous empirical studies conducted in EFL contexts $[13$, p. $264 ; 24$, p. 136] but not those conducted in ESL contexts [30, p. 140; 35, p. 255]. This is probably because NNESTs and their learners in EFL contexts are usually from the same linguistic background, but this may not be the case in ESL contexts. In this study, it was reported that NNETs made use of the L1 to explain difficult vocabulary items and grammar rules. NNETs' ability to anticipate learners' learning problems 
or needs supports two other positive aspects of NNESTs hypothesized by Medgyes (1994): "anticipate and prevent language difficulties better" and "be more empathetic to the needs and problems of learners" [30].

This discovery should enhance the self-esteem and professional confidence of non-NEST multilinguals, and should also enhance their reputation in the EFL profession.

The results also show that participants' preferences for NEST increase as they go up higher in their education, based on their previous learning experiences. Study subjects also showed a high clear preference for NESTs over NNESTs for the reaching strategies adopted by both types of teachers. Students believe that NEST uses motivating teaching methods that help them learn the language better and more reliably. Nonetheless, respondents are aware of NNESTs the strengths of their, which can provide a serious learning environment and are able to meet the needs of learners. Although the students clearly had a preference for NEST, they actually showed warmer feelings for NNEST. Students made it clear that they do not behave differently with both types of teachers and they focus on their strengths.

\section{Conclusion}

Affected by globalization, Ukrainian parents and students are more or less changing their impression toward native-speaking English teachers. They expect native English teachers teach "real" and "authentic" English, namely the accepted standard English. Foreign teachers are also more popular because of their appearance, way of talking, and flexible teaching approach [24, p. 137; 30, p. 145; 32, p. 347]. The reality, however, is very different in terms of teaching approaches, teaching attitude, and knowledge of English. For NES instructors to teach better and local students to learn more, the expectation gap between NES teachers and local students needs to be bridged. This can be done in a myriad of policies and measures. Here we suggest three possible ways to amend this perceptual deviance that may harm the teaching and learning process. First, universities and high schools should consider how to interact with NES teachers in an orientation meeting for incoming new students before any EFL course begins if there are NES teachers working for the institute. They should also offer training sessions for NES teachers who have little experiences teaching students from a different culture. Second, the higher school might consider having 
a NES teacher team up with a local teacher or teaching assistant to make the instruction more effective until NESTs acquire a basic cultural knowledge and learn the students' learning styles. In addition, NESTs can be trained to teach grammar as many teachers in Ukraine usually use the grammartranslation method as communication skills are not part of the assessment at secondary level of education. In a similar vein, NESTs will benefit from training as in-service English teachers, especially for the EFL environment. Third, both NES teachers and local teachers are suggested to rethink their roles and adjust self-expectation as the world changes rapidly. The most direct way to close the conceptual gap between the teacher and students is to take time to discuss it.

The study also brings up some important issues about who might be the best teacher, given the students' EF language level. The results highlight that NEST is best suited for students with higher English proficiency and for teaching communication-based lessons, however NNEST may work better with students at elementary level, especially for teaching grammar. In the same vein, some scholars find that students prefer teachers who speak local language and can explain language issues to them, and that students also know about English fluency and correct pronunciation [9, p. 48]. As a humble suggestion, we remind you of the importance of combining meaning, form and function. Therefore, the use of authentic supporting materials can be beneficial for NNESTs. Similarly, Coady (2015) emphasizes the role of field experience as a "learning potential for teachers" [16]. Combining these views the study suggests that teacher training programs instruct teachers by reminding them of these issues and encouraging them to practice.

\section{References:}

1. Arikan, A., Taşer, D., \& Saraç-Süzer, H. S. (2008). The effective English language teacher from the perspectives of Turkish preparatory school students. Education and Science, 33(150): 42-51.

2. Arva, V., Medgyes, P. (2000). Native and non-native teachers in the classroom. System, 28: 355-372.

3. Benke, E., Medgyes, P. (2005). Differences in teaching behavior between native and nonnative speaker teachers: As seen by the learners. In E. Llurda (Ed.), Nonnative language teachers: Perceptions, challenges and contributions to the profession. New York, NY: Springer: 195-215.

4. Boyle, T. (2002). Towards a Theoretical Base for Educational Multimedia Design. Journal of Interactive Media in Education, 2. doi: 10.5334/2002 
5. Cheung, Y. L., Braine, G. (2007). The attitudes of university students towards non-native speaker English teachers in Hong Kong. RELC Journal, 38, 257-277.

6. Chiba, R., Matsuura, H., Yamamoto, A. (1995). Japanese attitudes towards English accents. World Englishes, 14: 77-86.

7. Coady, Maria R., Harper, Candace, \& de Jong, Ester J. (2015). Aiming for Equity: Preparing Mainstream Teachers for Inclusion or Inclusive Classrooms? TESOL Quarterly, 50(2): 340-368.

8. Cook, V. (1999). Going beyond the native speaker in language teaching. TESOL Quarterly, 33(2), 185-209. doi: 10.2307/3587717

9. Denzin, N. K., \& Lincoln, Y. S. (2005). Introduction: The discipline and practice of qualitative research. In N. K. Denzin \& Y. S. Lincoln (Eds.), The Sage handbook of qualitative research, pp. 1-32. Thousand Oaks, CA: SAGE.

10. Dornyei, Z. (2007). Research methods in applied linguistics. Oxford, UK: Oxford University Press.

11. Ebele, T. (1999). The cultural capital of waiguoren English teachers. The Proceedings of the Eighth International Symposium on English Teaching. Taipei: $331-340$.

12. Ellis, E. (2002). Teaching from experience: A new perspective on the nonnative teacher in adult ESL. Australian Review of Applied Linguistics, 25: 71-107.

13. Kachru, B. (1996). The paradigms of marginality. World Englishes, 15: 241-255. doi: 10.1111/j.1467-971X.1996.tb00112.x

14. Kaplun, O. A. (2011) Grammaticheskaia kompetentsiia kak sostavliaiuschaia komunikativnoi kompetentsii. Uchenyie zapiski Orlovskogo gosudarstvennogo universiteta. Seriia: Humanitarnyie i sotsialnyie nauki, 4: 331-338. (in Russian)

15. Kashnikova, I. V., Chernova, L. E. (2011). Komunikativnyie praktiki etno-natsionalnyh menshinstv i fenomen bilingvizma. Filosofia politologa $v$ kontekste sovremennoi kultury, 2: 438-448. (in Russian)

16. Kelch, K., Santana-Williamson, E. (2002). ESL students' attitudes toward native- and non-native-speaking instructors' accents. CATESOL Journal, 14(1): $57-72$.

17. Kirkpatrick, A. (2007). World Englishes: Implications for international communication and English language teaching. Cambridge, UK: Cambridge University Press.

18. Kravchenko, A. V. (2009). Nositeli iazyka, rodnoi iazyk, i drugiie interesnyie veshchi. Aktualnyie problemy filologii pedagogicheskoi lingvistiki, 11: 29-37. (in Russian)

19. Lasagabaster, D., \& Sierra, J. (2002). University Students' Perceptions of Native and Non-native Speaker Teachers of English. Language Awareness, 11(2): 132-138. doi: 10.1080/09658410208667051

20. Lee, J. (2005). The native speaker: An achievable model? Asian EFL Journal, 7(2).

21. Liang, K. (2002). English as second language (ESL) students 'attitudes towards nonnative English speaking teachers'accentedness (Unpublished master's thesis). California State University, Los Angeles. 
22. Liu, M., Zhang, L. (2007). Student Perceptions of Native \& Non-native English Teachers' Attitudes, Teaching Skills Assessment and Performance. Asian EFL Journal, 9(4), Conference Proceedings: 157-166.

23. Lovtsevich, G. N. (2010). Krosskulturnyi terminologicheskiy slovar kak sredstvo representatsii terminologii gumanitarnykh nauk. Vladivostok: Izdatelstvo Dalnevostochnogo universiteta. (in Russian)

24. Luk, J. (1998). Hong Kong students' awareness of and reactions to accent differences. Multilingua, 17: 93-106.

25. Madrid, D. (2004). Teacher and Student Preferences of Native and Nonnative Foreign Language Teachers. Porta linguarum, 2: 125-138.

26. Mahboob, A. (2003). Status of non-native English speaking teachers in the United States. Unpublished Ph.D. Dissertation. Indiana University, Bloomington: NY: 147.

27. McDonald, C., McRae, S. (2010). A pre-trial collection and investigation of what perceptions and attitudes of Konglish exist amongst foreign and Korean English language teachers in terms of English education in Korea. Asian EFL Journal, 12(1): 134-164.

28. Medgyes, P. (1992). Native or non-native: Who's worth more? ELT Journal, 46(4): 340-349. doi: 10.1093/elt/46.4.340

29. Medgyes, P. (1994). The non-native teacher. London: Macmillan, 340-349.

30. Moussu, L. (2010). Influence of teacher-contact time and other variables on ESL students' attitudes towards native- and nonnative English-speaking teachers. TESOL Quarterly, 44: 746-768.

31. Nosonovich, E. V., Milrud, R. P. (1999). Parametry autentichnogo uchebnogo teksta. Inostrannyie iazyki v shkole, 1, 11-18. (in Russian)

32. Proshina, Z. G. (2012). Smena paragigmy iazykovogo obrazovaniia? Lichnost. Kultura. Obschestvo. 14-2-71/72: 176-177. (in Russian)

33. Pacek, D. (2005). "Personality not nationality": Foreign students' perceptions of a non-native speaker lecturer of English at a British university. In E. Llurda (Ed.). Nonnative language teachers: Perceptions, challenges and contributions to the profession, pp. 243-261. New York, NY: Springer.

34. Park, E. (2009). The Korean university students' preferences toward native English teachers. Modern English Education, 10(3): 114-130.

35. Phillipson, R. (1996). ELT: The native speaker's burden. In T. Hedge, \& N. Whitney (Eds.). Power, pedagogy \& practice. Oxford: Oxford University Press: 23-30.

36. Scovel, J. (1983). English teaching in China: A historical perspective. Language Learning and Communication, 2(1): 105-109.

37. Shchukin, A. N. (2006). Obucheniie inostrannym iazykam: teoriia i praktika: posobiie dlia prepodavetelei i studentov. Moskva: Filomatis. (in Russian)

38. Shibata, M. (2010). How Japanese teachers of English perceive non-native assistant English teachers. System, 38: 124-133.

39. Shirina, M. S. (2013). Polikulturnaiia sreda kak usloviie formirovaniia sotsiokulturnoi kompetentsii $\mathrm{v}$ protsese inoiazychnogo obrazovaniia obrazovaniia budushchikh kadrov ekonomicheskoi sfery. URL: http://scientific-notes.ru/index. php?page $=6 \&$ new $=33$ 
40. Suarez, J. (2000). 'Native' and 'non-Native': not only a question of terminology. Humanizing Language Teaching, 2(6). URL: http://www.hltmag.co.uk/ nov00/martl.htm

41. Todd, R., Pojanapunya, P. (2009). Implicit attitudes toward native and non-native speaker teachers. System, 37(1): 23-33. doi: 10.1093/elt/46.4.340

42. Torres, J. (2004). Speaking Up! Adult ESL Students' Perceptions of Native and Non-Native English Speaking Teachers. Unpublished MA Thesis, University of North Texas.

43. Walkinshaw, I., \& Duong, O. T. H. (2012). Native- and non-native speaking English teachers in Vietnam: Weighing up the benefits. TESL-EJ, 16(3): 1-17.

44. Wu, K.-H., Ke, C. (2009). Haunting native speakerism? Students' perceptions toward native speaking English teachers in Taiwan. English Language Teaching, 2(3): 44-52.

45. Widdowson, H. G. (1994). The ownership of English. TESOL Quarterly, 28(2), 377-389. doi: 10.2307/3587438

46. Xiaoru, C. (2008). A SURVEY: Chinese College Students' Perceptions of Non-Native English Teachers. CELEA Journal, 31(3): 75-82. 